\title{
Lobbyists as Imperfect Agents: Implications for Public Policy in a Pluralist System
}

\section{Citation}

Matthew Stephenson \& Howell E. Jackson, Lobbyists as Imperfect Agents: Implications for Public Policy in a Pluralist System, 47 Harv. J. on Legis. 1 (2010).

\section{Permanent link}

http://nrs.harvard.edu/urn-3:HUL.InstRepos:10849855

\section{Terms of Use}

This article was downloaded from Harvard University's DASH repository, and is made available under the terms and conditions applicable to Open Access Policy Articles, as set forth at http:// nrs.harvard.edu/urn-3:HUL.InstRepos:dash.current.terms-of-use\#OAP

\section{Share Your Story}

The Harvard community has made this article openly available.

Please share how this access benefits you. Submit a story.

\section{Accessibility}




\title{
ESSAY
}

\section{LOBBYISTS AS IMPERFECT AGENTS: IMPLICATIONS FOR PUBLIC POLICY IN A PLURALIST SYSTEM*}

\author{
Matthew C. Stephenson $\$$ \& Howell E. Jackson†
}

\begin{abstract}
Interest group pluralism presumes that public policy outcomes are determined principally through a contest for influence among organized pressure groups. Most interest groups, however, do not represent themselves in this process. Rather, they rely on professional lobbyists for representation, information, and advice. These lobbyists, however, may have their own interests, which may not align perfectly with those of their clients. This Essay outlines this principalagent problem and suggests its possible implications for policy outcomes. In particular, this piece hypothesizes that the lobbyist-client agency problem may create four notable consequences: (1) it may bias policy in favor of small homogenous groups; (2) it may exacerbate status quo bias; (3) it may promote expansive delegations of power and rulemaking to administrative agencies; and (4) it may impede systematic reforms to the policymaking process.
\end{abstract}

\section{INTRODUCTION}

The dominant framework for understanding public policymaking in the United States is interest group pluralism. ${ }^{1}$ According to the pluralist view, the best way to explain and predict policy outcomes is to focus on the many organized groups jostling to advance their interests through government action. $^{2}$ A robust theoretical, empirical, and normative debate exists over

*The authors are grateful to Gabriella Blum, Glenn Cohen, Jake Gersen, Daryl Levinson, A.G. Newmyer, Jeff Pojanowski, Ben Roin, Ben Sachs, Jed Shugerman, Tom Susman, and Judge Stephen Williams for helpful comments on earlier drafts.

\$Assistant Professor, Harvard Law School.

$\dagger$ hmes S. Reid, Jr., Professor of Law, Harvard Law School.

${ }^{1}$ See, e.g., Daniel A. Farber \& Philit P. Frickey, Law and Public Choice: A CritiCAL INTRODUCTION 12-15 (1991).

${ }^{2}$ Classic statements of the pluralist perspective on policymaking include Arthur F. Bentley, The Process of Government: A Study of Social Pressures (1908); James M. Buchanan \& Gordon Tullock, The Calculus of Consent (1962); Robert A. Dahl, A Preface to Democratic Theory (1956); Robert A. Dahl, Who Governs? Democracy and Power in an American City (1961); Earl Latham, The Group Basis of Politics: A Study in Basing-Point Regulation (1952); David B. Truman, The Governmental ProCess: Political Interests and Public Opinion (1951). More recent treatments of interest group pluralism in political science and law include JefFrey M. Berry, The Interest Group Society (2d ed. 1989); Daniel A. Farber \& Philip P. Frickey, Law and Public Choice: A Critical Introduction (1991); Kay Lehman Schlozman \& John T. Tierney, Organized Interests and American Democracy (1986); Arthur T. Denzau \& Michael C. Munger, Legislators and Interest Groups: How Unorganized Interests Get Represented, 80 Ам. PoL. ScI. Rev. 89 (1986); William N. Eskridge, Jr., Politics Without Romance: Implications of Public Choice Theory for Statutory Interpretation, 74 VA. L. REv. 275 (1988); William C. Mitchell \& Michael C. Munger, Economic Models of Interest Groups: An Introductory Survey, 35 Ам. 
whether this sort of interest group pluralism is good or bad. While critics fear that interest group pluralism leads to unjust or inefficient outcomes, ${ }^{3}$ more optimistic observers believe that pluralism, despite its flaws, produces reasonably good public policy most of the time. ${ }^{4}$ Both defenders of pluralism and its critics, however, generally share an implicit belief that each group zealously advocates for whatever policies would best advance its own interests. ${ }^{5}$ While this is a useful first approximation, it overlooks the fact that interest groups usually rely on professional lobbyists to represent them in the political process. ${ }^{6}$ The relationship between an interest group and its lobbyists is therefore vulnerable to the kinds of problems common between any principals and agents. These agency problems may distort the policymaking process in ways that lead to outcomes that differ from those that would prevail under "pure" interest group pluralism, where the aims of the interest groups fully determine their lobbyists' actions.

The existing literature has noted the potential agency problem between lobbyists and their clients. ${ }^{7}$ This issue has not, however, received the atten-

J. Pol. ScI. 512 (1991); Cass Sunstein, Interest Groups in American Public Law, 38 Stan. L. REV. 29 (1985). Although this literature focuses principally on the United States, interest group (or "stakeholder") theories of policymaking have also been applied, often with considerable success, in other contexts. See Bruce Bueno de Mesquita \& Frans Stokman, European Community Decision Making (1994); Bruce Bueno de Mesquita et al., Red Flag Over Hong Kong (1986).

${ }^{3}$ See Buchanan \& Tullock, supra note 2; Mancur Olson, The Logic of Collective Action: Public Goods and the Theory of Groups (1965); Mancur Olson, The Rise and Decline of Nations (1982); Sam Peltzman, Toward a More General Theory of Regulation, 19 J.L. \& ECON. 211 (1976); Richard A. Posner, Theories of Regulation, 5 Bell J. Econ. \& Mgmt. Sci. 22 (1974); George J. Stigler, The Theory of Economic Regulation, 2 Bell J. Econ. \& Mgmt. ScI. 3 (1971).

${ }^{4}$ See Gary Becker, A Theory of Competition Among Pressure Groups for Political Influence, 98 Q.J. ECON. 371 (1983); Herbert Hovenkamp, Legislation, Well-Being, and Public Choice, 57 U. CHI. L. Rev. 63 (1990); Mark Kelman, On Democracy-Bashing: A Skeptical Look at the Theoretical and "Empirical" Practice of the Public Choice Movement, 74 VA. L. Rev. 1999 (1988); Donald Wittman, Why Democracies Produce Efficient Results, 97 J. Pol. ECON. 1395 (1989).

${ }^{5}$ Compare Buchanan \& Tullock, supra note 2, at 78, with Dahl, A Preface to DemoCRATIC THEORY, supra note 2, at 15.

${ }^{6}$ See, e.g., Richard A. Smith, Interest Group Influence in the U.S. Congress, 20 LEGIS. STUD. Q. 89 (1995).

${ }^{7}$ The most sustained analysis of this lobbyist-client agency problem is Rogan Kersh, State Autonomy \& Civil Society: The Lobbyist Connection, 14 Critical Rev. 237 (2000). Kersh emphasizes that lobbyists are not mere "transmission belts" who represent their clients' interests in the legislative process; rather, he points out, lobbyists have their own interests-both material and with respect to public policy_that may differ from those of their clients. The current analysis differs from Kersh's in that Kersh's principal interest is in the implications of lobbyist autonomy for theories of state autonomy and civil society, whereas this Essay is interested primarily in whether lobbyist-client agency slack may have systematic consequences for public policy. On this question, the legal literature contains numerous scattered references to how the divergence between lobbyist interests and client interests may affect policy outcomes, but little sustained attention. See Scott Baker \& Kimberly D. Krawiec, The Penalty Default Canon, 72 Geo. WASH. L. Rev. 663, 676 (2004) (suggesting that a client-lobbyist agency problem explains why groups fail to object when a statute is incomplete and shifts responsibility to courts or administrative agencies); Steven P. Croley, Theories of Regulation: Incorporating the Administrative Process, 98 Colum. L. Rev. 1, 61-62 \& n.174 (1998) (discussing the 
tion it deserves. This lack of sustained analysis of agency problems in the lobbying context is surprising, given the rich and sophisticated literature that considers analogous agency problems between lawyers and their clients. ${ }^{8}$

possibility that environmental and consumer advocacy groups represent the interests of their leadership rather than the interests of their members or the public at large); Clayton P. Gillette, Rules, Standards, and Precautions in Payment Systems, 82 VA. L. REv. 181, 201-03 (1996) (claiming, in general, that an agency problem means interest group leaders will sometimes push legislation that benefits the leaders more than their constituents, perhaps by focusing on securing visible and popular benefits at the expense of less salient but more important benefits); Michael S. Greve, Business, the States, and Federalism's Political Economy, 25 Harv. J.L. \& PUB. POL'y 895, 922 (2002) (arguing that a principal-agent problem between lobbyists and their constituents may explain why both environmentalists and the business community might prefer a federal permitting program to a decentralized, state-level regulatory system, even if the latter would be better both for business and the environment); Robert W. Hahn \& Robert N. Stavins, Incentive-Based Environmental Regulation: A New Era from an Old Idea?, 18 ECOLOGY L.Q. 1, 25 (1991) (arguing that the resistance of industry lobbyists to marketbased environmental regulations stems, in part, from a principal-agent problem because the lobbyists fear changes to the status quo that would diminish the value of their expertise, even if these changes would benefit their clients); Thomas W. Hazlett, Physical Scarcity, Rent Seeking, and the First Amendment, 97 Colum. L. Rev. 905, 931-32 \& n.103 (1997) (arguing that an agency problem between non-profit broadcasters and their lobbyists explains why nonprofits supported the licensing scheme adopted by the 1927 Radio Act, even though it was not in their interest); Samuel Issacharoff \& Daniel R. Ortiz, Governing Through Intermediaries, 85 VA. L. REv. 1627, 1652-54 (1999) (observing that although citizens can make use of "superagents," including organized interest groups, to monitor their political representatives, these superagents might themselves be subject to agency problems); Nathaniel O. Keohane et al., The Choice of Regulatory Instruments in Environmental Policy, 22 HARv. EnVTL. L. REv. 313, 332-33 (1998) (asserting that a principal-agent problem exists between an interest group's members and the professional staff who engage in lobbying activities); Manik Roy, Pollution Prevention, Organizational Culture, and Social Learning, 22 EnvTL. L. 189, 205 (1992) (observing, in a case study of an environmental advocacy group, that the group's lobbyist had tremendous discretion and independence from the group's contributors); Henry A. Span, Public Choice Theory and the Political Utility of the Takings Clause, 40 IDAHo L. REv. 11, 35 n.101 (2003) (noting that lobbyists claiming to represent diffuse groups may exhibit an agency problem); Nathan Witkin, Interest Group Mediation: A Mechanism for Controlling and Improving Congressional Lobbying Practices, 23 OHIo St. J. on Disp. Resol. 373, 402 \& n.258 (2008) (arguing that an agency problem may lead lobbyists to oppose interest group mediation mechanisms that might benefit their clients); Todd J. Zywicki, Environmental Externalities and Political Externalities: The Political Economy of Environmental Regulation and Reform, 73 Tul. L. REv. 845, 877-80 (1999) (arguing that the environmental groups that lobby policymakers have organizational interests that are separate from, and sometimes conflict with, the interest in environmental protection, and that this explains their preference for centralized, command-and-control regulation); David Freeman Engstrom, The Lost Origins of American Fair Employment Law: Regulatory Choice and the Making of Modern Civil Rights, 1943-1964 (Mar. 3, 2009) (unpublished manuscript, on file with the Harvard Journal on Legislation) (suggesting that the organizational interests of mainstream civil rights groups influenced these groups' decisions to push for administrative, rather than legal, solutions to employment discrimination problems in the 1940s and 1950s, despite evidence that a courtcentered strategy might be more effective).

${ }^{8}$ See Derrick A. Bell, Jr., Serving Two Masters: Integration Ideals and Client Interests in School Desegregation Litigation, 85 YALE L.J. 470 (1976); John C. Coates IV, Explaining Variation in Takeover Defenses: Blame the Lawyers, 89 CAL. L. Rev. 1301 (2001); John C. Coffee, Understanding the Plaintiff's Attorney: The Implications of Economic Theory for Private Enforcement of Law Through Class and Derivative Actions, 86 Colum. L. Rev. 669 (1986); John C. Coffee, The Unfaithful Champion: The Class Attorney as a Monitor in Shareholder Litigation, 48 LAw \& Contemp. Probs. 5 (1985); James D. Dana, Jr. \& Kathryn E. Speir, Expertise and Contingent Fees: The Role of Asymmetric Information in Attorney Com- 
Just as puzzling patterns in litigation and settlement outcomes become more easily explainable when one considers that lawyers are not always perfect agents of their clients, ${ }^{9}$ so too might certain legislative outcomes become more comprehensible when viewed in light of the fact that lobbyists are not always perfect agents either.

This Essay explores the lobbyist-constituent agency problem and its implications for public policy. The Essay draws on the scattered examples of lobbyist-constituent agency problems in the existing literature, as well as general principal-agent theory, to develop a more comprehensive account of the causes and possible consequences of the lobbyist-constituent agency problem for legislative outcomes. The Essay then advances four tentative hypotheses as to the systematic effects that this agency problem may have on public policy: (1) increased bias in favor of small homogenous interest groups; (2) exacerbated status quo bias; (3) amplified legislative delegation to administrative agencies; and (4) systematic impediments to reform.

The argument is limited in several ways. The lobbyist-constituent agency problem does not provide a complete explanation for puzzling policy choices any more than the lawyer-client agency problem provides a complete account of litigation and settlement outcomes that do not seem completely consonant with the parties' interests. Nor does this Essay aspire to establish rigorously the existence or extent of the agency problem in any particular context. Its goal-more modest, but nonetheless significant-is to convince students of the policymaking process in the United States that they should take the lobbyist-constituent agency problem at least as seriously as students of litigation and negotiation treat the lawyer-client agency problem. Consideration of the lobbyist-constituent agency problem should be a regular fixture, rather than an occasional afterthought, in analyses of pluralist policymaking.

\section{The Sources of the Lobbyist-Constituent Agency Problem}

Various entities and interest groups attempt to influence government policymaking in pursuit of an extraordinarily diverse array of objectives. Business firms want a favorable regulatory and tax environment that will increase their profits. Members of the labor force want employment opportu-

pensation, 9 J.L. Econ. \& ORg. 349 (1993); Winand Emons, Expertise, Contingent Fees, and Insufficient Attorney Effort, 20 InT'L Rev. L. \& ECON. 21 (2000); Ronald J. Gilson \& Robert H. Mnookin, Disputing Through Agents: Cooperation and Conflict Between Lawyers in Litigation, 94 Colum. L. Rev. 509 (1994); Bruce L. Hay, Contingent Fees and Agency Costs, 25 J. Legal Stud. 503 (1996); Bruce L. Hay, Effort, Information, Settlement, Trial, 24 J. Legal Stud. 29 (1995); Thomas Miceli, Do Contingent Fees Promote Excessive Litigation?, 23 J. Legal Stud. 211 (1994); Geoffrey P. Miller, Some Agency Problems in Settlement, 16 J. Legal Stud. 189 (1987); A. Mitchell Polinsky \& Daniel L. Rubinfeld, Aligning the Interests of Lawyers and Clients, 5 AM. L. \& ECON. Rev. 165 (2003); Alison Watts, Bargaining Through an Expert Attorney, 10 J.L. ECON. \& ORG. 168 (1994).

${ }^{9}$ See supra note 8 and accompanying text. 
nities, high wages, and a safe working environment. Universities want government subsidies for academic research. Environmentalists want clean air and water, as well as protection of endangered species and ecosystems. Virtually all of these organized interest groups rely on professional lobbyists to represent their interests. ${ }^{10}$

Public policy lobbying in the United States is a multi-billion dollar industry, and there are tens of thousands of lobbyists operating in Washington, D.C. alone. ${ }^{11}$ Some organizations have their own in-house lobbyists, while others employ "contract lobbyists"- typically public relations firms or law firms. ${ }^{12}$ Some interest groups, particularly businesses, lobby through trade associations, which are difficult to classify as either in-house or contract lobbyists because the lobbyists are often employed directly by the association, but the association consists of many members. ${ }^{13}$ Also, many organizations rely on a combination of in-house and contract lobbyists, just as some companies may rely on a combination of in-house counsel and outside law firms. ${ }^{14}$

These professional lobbyists perform a number of important services for their clients. Most obviously, they advocate for their clients' interests in the policymaking process. In doing so, lobbyists make use of specialized skills, including their expertise in navigating legislative and administrative decision-making processes, their personal contacts and relationships with key policymakers, and their ability to marshal and disseminate information and arguments that put their clients' preferred policies in the best possible

${ }^{10}$ See John R. Wright, Interest Groups And Congress 22-30 (1996). For an online database of lobbyists for interest groups and other entities, see the Center for Responsive Politics compilation of lobbying reports filed with the Senate's Office of Public Records. Center for Responsive Politics, Lobbying Database, http://www.opensecrets.org/lobby/index. php (last visited Nov. 1, 2009). In this Essay, the authors use the term "lobbyist" expansively to cover not only individuals or entities that must register as lobbyists under the relevant federal lobbying statutes, but also all those who are employed by interest groups to monitor government activities, to formulate strategies to influence government behavior, and to advocate on interest groups' behalf before government bodies (including legislatures, administrative agencies, and in some cases, courts). Thus this definition of lobbyists would include much of the work of lawyers and other professionals, including consultants and public relations firms. These findings would also be applicable to lobbying at other levels of government. $9-11$.

${ }^{11}$ See Anthony J. Nownes, Total Lobbying 12 (2006); Wright, supra note 10, at at 43 .

${ }^{12}$ See John P. Heinz et Al., The Hollow Core 64-66 (1993); Nownes, supra note 11,

${ }^{13}$ For a useful discussion of trade associations, as well as an analysis of why firms might sometimes prefer this mode of lobbying activity, see Sanford C. Gordon \& Catherine Hafer, Endogenous Trade Associations in Regulatory Politics (Oct. 15, 2009) (unpublished manuscript, on file with authors).

${ }^{14}$ For example, according to Center for Responsive Politics compilations, the U.S. Chamber of Commerce retains in-house lobbyists and also hires outside lobbying firms. Center for Responsive Politics, Lobbying Spending Database_U.S. Chamber of Commerce 2009, http:// www.opensecrets.org/lobby/clientsum.php? Iname $=\mathrm{US}+$ Chamber + of + Commerce \&year $=$ 2009 (last visited Nov. 1, 2009). 
light. ${ }^{15}$ In addition to their advocacy function, lobbyists monitor the legislative and administrative processes and provide their clients with information about developments that are likely to affect the clients' interests. ${ }^{16}$ Lobbyists are a critical source of information not only because clients often do not have the time or resources to do the monitoring themselves, but also because a professional lobbyist's familiarity with the policymaking process allows them to be more efficient monitors of emerging issues and more accurate predictors of the consequence of proposed reforms. ${ }^{17}$ The role of lobbyists as monitors of the policy process is especially important for large membership organizations and for more complex or arcane policy areas where individual members have weak incentives to monitor the activities of the government on their own..$^{18}$

In addition to providing advocacy and monitoring services, lobbyists also give their clients strategic advice about what policies to support and how that advocacy should be undertaken. ${ }^{19}$ Indeed, one researcher reported that when he asked a sample of industry executives what their top priorities were in terms of federal health care policy, the most common answer was, "Whatever our firm's lobbyists say they are." ${ }^{20}$ One well-known example of how professional lobbyists can influence an interest group's legislative strategy is the automobile industry's decision to support federal pollution control standards in the 1960 s, a policy that the industry had previously opposed. ${ }^{21}$ The suggested change in the auto industry's strategy apparently came from the prominent lawyer Lloyd Cutler, who advised his auto industry clients that they would be better off with a federal statute that would preempt the state anti-pollution statutes that were starting to appear. ${ }^{22}$ Just as Cutler's advice shaped the auto industry's lobbying strategy on federal clean air legislation, other lobbyists similarly shape their clients' lobbying strategies by recommending or discouraging different approaches. The lobbyists' expertise and experience makes it likely that their clients will pay close attention to their advice. Moreover, in addition to their influence over general strategy,

15 See Scott H. Ainsworth, Analyzing Interest Groups 120-21 (2002); Nownes, supra note 11, at 16-19, 26-28; WrIGHT, supra note 10, at 88-113.

${ }^{16}$ See Nownes, supra note 11, at 31-32, 44-46.

${ }^{17}$ See Robert H. Salisbury et al., Who You Know Versus What You Know: The Uses of Government Experience for Washington Lobbyists, 33 AM. J. PoL. SCI. 175 (1989) (discussing value of lobbyist knowledge of substance policy and decision-making processes).

${ }^{18}$ See Span, supra note 7 , at 35 .

${ }^{19}$ See id. at 51-52.

${ }^{20}$ See Kersh, supra note 7, at 242; see also id. at 244-45 (noting that many lobbyists spend more time explaining issues to their clients than getting instructions from their clients and that lobbyists are responsible for identifying many of their clients' interests for them).

${ }^{21}$ See David Schoenbrod, Power Without Responsibility: How Congress Abuses the People Through Delegation 59 (1993); E. Donald Elliott et al., Toward a Theory of Statutory Evolution: The Federalization of Environmental Law, 1 J.L. ECON. \& ORG. 313, 331 (1985).

${ }^{22}$ Schoenbrod, supra note 21 , at 59. 
many lobbyists have an enormous amount of de facto discretion over tactics, including subtle decisions concerning levels of effort on different issues. ${ }^{23}$

The extent of various constituency groups' reliance on professional lobbyists for advocacy, for information, and for advice suggests at least the possibility of an agency problem. Additionally, it is difficult and costly for the client to monitor the lobbyist's activities, including both the lobbyist's overall effort and the lobbyist's specific tactical decisions. Although the client may be able to observe a final policy outcome, it is difficult for the client to disentangle how much of the final outcome is due to its lobbyist's efforts and how much of it is due to factors beyond the lobbyist's control. ${ }^{24}$

Moreover, evaluating the impact of a policy outcome on the client's welfare involves a comparison between the actual outcome and one or more unobserved counterfactuals. Even if the client is happy with the legislation that Congress adopted, or happy that Congress did not adopt legislation, the client does not know if it would have been even better off with a different legislative outcome. Likewise, even when a policy outcome appears adverse to the client's interests, the lobbyist may often assert that it was the best achievable result, and any alternative would have been even worse. Such assertions are often, but not always, accurate, and it is difficult for a client to identify those situations where the lobbyist is deliberately or subconsciously bending the truth.

These agency problems are likely more acute for advocacy groups with broad and diffuse membership than for single entities or narrower groups, due to both the greater heterogeneity of underlying interests and greater costs of monitoring the membership. Agency problems are also probably more severe for organizations that rely on contract lobbyists than for organizations that engage in direct lobbying because the potential divergence of interest between a client and a contract lobbying firm is typically greater than the divergence of interest between an organization and its in-house lobbying personnel. Further, it is probably also more costly to monitor behavior in the former case. ${ }^{25}$ Likewise, the agency problem may be more serious with regard to broad-based trade associations, whose interests may be imperfectly aligned with those of their members or whose members themselves

${ }^{23}$ See Kersh, supra note 7, at 245.

${ }^{24}$ Cf. David Austen-Smith \& Jeffrey Banks, Electoral Accountability and Incumbency, in Models of Strategic Choice in Politics 121 (Peter C. Ordeshook ed., 1989) (stating that it is difficult to ascribe responsibility for any particular policy outcome to a particular legislator); Scott Ashworth \& Ethan Bueno de Mesquita, Delivering the Goods: Legislative Particularism in Different Electoral and Institutional Settings, 68 J. PoL. 168 (2006); John Ferejohn, Incumbent Performance and Electoral Control, 50 Pub. CHoice 5 (1986); Susanne Lohmann, An Information Rationale for the Power of Special Interests, 92 AM. PoL. ScI. Rev. 809 (1998).

${ }^{25}$ See Heinz ET AL., supra note 12, at 67. But see Kersh, supra note 7, at 254 n.9 (finding, in a sample of lobbyists, that the amount of lobbyist discretion seemed to depend on individual characteristics of the lobbyists themselves, not on whether the lobbyists represent single firms or larger associations, or on whether the lobbyists are in-house employees or outside "hired guns"). 
may have diverse or irreconcilable interests. ${ }^{26}$ Such problems mean that there is likely to be some opportunity for lobbyists to exploit their informational advantages in ways that benefit the lobbyists more than their clients.

To be sure, lobbyists are constrained in a number of ways. Clients may do what they can to monitor lobbyist activity. ${ }^{27}$ Clients may also try to design explicit or implicit incentive contracts to induce lobbyists to act as faithful agents or to attract lobbyists who are likely to do so. For example, clients can condition compensation (or repeat business) on results that clearly benefit client interests. ${ }^{28}$ Also, the competitive market for lobbyists might impose some discipline. Such market pressure might affect not only for-profit lobbying firms, but also advocacy organizations that must compete for members and donors.

Furthermore, lobbyists will often share their client's underlying interests to a considerable degree. This is especially true when professional lobbyists seek out a particular constituency or cause. For example, professionals who lobby on behalf of environmental causes have a stronger-than-average interest in environmental protection, as evidenced by the fact that they often forego more lucrative employment opportunities. ${ }^{29}$ In addition, advocates often come to internalize the values and interests of their clients and to see things from their clients' points of view. ${ }^{30}$

Nonetheless, it is likely that the congruence of lobbyist and client interests will often be imperfect. Four factors in particular may drive a wedge between the goals of the lobbyist and the client. First, the lobbyist's optimal level of effort is likely to differ from what would benefit the client most. This is because the lobbyist's net compensation, both monetary and nonmonetary, is unlikely to correspond perfectly to the net benefits her services confer on the client. ${ }^{31}$ In some cases, the marginal benefit to the client of an additional unit of lobbyist effort exceeds the marginal benefit to the lobbyist of investing that effort. In those cases, the lobbyist's effort is likely to be lower that what the client, if fully informed, would prefer. ${ }^{32}$ In other cases, the marginal benefit to the client of an additional unit of effort is less than

${ }^{26}$ For a recent, public example of such divergence, see Lisa Lerer, Nike to Quit Chamber Post in Climate Protest, Politico, Sept. 30, 2009, http://www.politico.com/news/stories/0909/ 27739.html.

${ }^{27}$ See HeINZ ET AL., supra note 12, at 59-79; Nownes, supra note 11, at 54-55.

${ }^{28}$ Thomas Susman \& Margaret Martin, Contingent Fee Lobbying: Inflaming Avarice or Facilitating Constitutional Rights, 31 Seton Hall Legis. J. 311 (2007).

${ }^{29}$ See Roy, supra note 7, at 205.

${ }^{30} \mathrm{Cf}$. Alec Walen, Criticizing the Obligatory Acts of Lawyers: A Response to Markovits's Legal Ethics from the Lawyer's Point of View, 16 Yale J.L. \& Human. 1, 39 (2004) (noting how lawyers may come to internalize their client's perspective).

${ }^{31}$ One contributing factor to this dynamic is that a lobbyist may have her own personal policy preferences, and these may affect how hard the lobbyist works to pursue certain goals. A lobbyist may have a stronger incentive to work hard if she agrees with the client's goals than if she does not. See Kersh, supra note 7, at 249-50. This may have public policy consequences with respect to particular issue areas that go beyond distortions in effort levels, but these consequences are for the most part idiosyncratic.

${ }^{32}$ Gillette, supra note 7, at 202. 
the marginal benefit the lobbyist would receive. In those cases, the lobbyist's total effort is likely to be too high from the client's perspective. ${ }^{33}$ Furthermore, precisely because certain aspects of lobbyist performance are easier to observe than others, a lobbyist has an incentive to distort her efforts in the direction of those activities that are more easily observable by the client, even if other forms of subtler, difficult-to-observe effort would better advance the client's underlying interests. ${ }^{34}$ Similarly, imperfect monitoring may give a lobbyist an incentive to achieve easily observable short-term successes that can be directly attributed to the lobbyist's efforts and an incentive to avoid easily observable defeats or more complicated strategies that may advance the long term interests of the client but not generate immediate payoffs.

The second reason that lobbyists' incentives may not align perfectly with their clients' interests is that lobbyists have an interest in the long-term value of their specific assets, the most important of which are expertise and reputation. ${ }^{35}$ In many cases, a lobbyist's interest in preserving the value of her specific assets will overlap with the client's interests in securing particular policy outcomes. A legislative victory, for example, both benefits the client and burnishes the lobbyist's reputation for reliability and efficacy. Sometimes, however, a lobbyist's interest in preserving the value of her human capital or other specific assets will be in tension with the client's interests in particular policy outcomes or lobbying strategies. Perhaps more importantly, some policy options that would benefit the client might also render the lobbyist's particular skills less valuable in the future, while other options, though less desirable for the client, may increase demand for the lobbyist's services. In these cases, the lobbyist may be tempted, perhaps subconsciously, to give advice or advance arguments that serve the lobbyist's long-term self-interest more than they benefit the client. ${ }^{36}$

A third reason why lobbyists' interests may diverge from the interests of their clients is that the lobbyists themselves may have personal policy interests that influence, at least at the margins, the sort of advice that lobbyists give to their clients. Further, these independent interests may influence how lobbyists exercise the discretion they inevitably possess. Some lobbyists are drawn into the work precisely because they believe in a particular cause; this dedication may sometimes lead to tension if the interests of a particular client do not perfectly align with the lobbyist's perception of what

${ }^{33}$ Id.

${ }^{34}$ That is, the lobbyist-client relationship may entail a multi-task moral hazard problem. See Bengt Holmstrom \& Paul Milgrom, Multitask Principal-Agent Analyses: Incentive Contracts, Asset Ownership, and Job Design, 7 J.L. Econ. \& Org. 24 (1991).

${ }^{35}$ Kevin W. Hula, Lobbying Together: Interest Group Coalitions in Legislative PoLitics 95 (1999) (identifying reputation as an "important source of political capital").

${ }^{36}$ Cf. Steve John, The Persuaders: When Lobbyists Matter 43 (2002) (noting the importance of long-term relationships to lobbyists). 
would be in the interest of the larger cause. ${ }^{37}$ Additionally, many lobbyists have previously served with the government branch or agency that they are now attempting to influence, and some harbor ambitions of returning to government service or, at least, seek to maintain close relationships with government personnel. ${ }^{38}$ This may lead lobbyists, either out of instrumental career concerns or subconscious identification, to see things from the perspective of the relevant government agents, which may differ from the perspective of the client.

Finally, professional lobbyists likely value good relations with other lobbyists. This professional imperative may inhibit one lobbyist from advancing positions that modestly benefit the lobbyist's own client if the positions would substantially harm the interests of clients of other lobbyists with whom the first lobbyist hopes to work in the future. For example, imagine a client with little capacity to benefit from congressional earmarks. ${ }^{39}$ It might be in the client's interest to support a categorical ban on earmarks, but the client's lobbyist may be reluctant to recommend or champion such a ban because this action could antagonize other lobbyists and diminish the ability of those lobbyists to obtain earmarks for their clients. Collegial relations with fellow lobbyists is thus another form of human capital that may put distance between the interests of lobbyists and those of their clients.

To be clear, this Essay does not argue that lobbyists engage in deliberate subversion of their clients' interests. Perhaps this sort of bad faith behavior occurs sometimes, but it is likely uncommon. Far more plausible is that lobbyists, like other human beings, have a tendency to believe that what is good for their clients is what happens to be good for them as well. Thus even when lobbyists act entirely in good faith, their self-interest may cloud or distort their judgment of what would best serve their clients' interests. ${ }^{40}$ The question then becomes whether this distortion has systematic consequences for public policy. lawyers)

${ }^{37} \mathrm{Cf}$. Bell, supra note 8 (making the analogous point with respect to public interest

${ }^{38}$ This implies that, insofar as government entities have their own institutional interests, which do not necessarily reflect the interests of their various constituencies or the general public, lobbyists who sympathize or identify with these entities may "inherit" some of their particular institutional interests. These inherited preferences, in turn, may sometimes diverge from the interests of lobbyists' clients.

${ }^{39}$ For an overview of federal earmarks, see Robert Porter \& Sam Walsh, Earmarks in the Federal Budget Process (Apr. 1, 2008) (unpublished student paper), available at http://www. law.harvard.edu/faculty/hjackson/budget.php).

${ }^{40}$ See Jason Dana \& George Loewenstein, A Social Science Perspective on Gifts to Physicians from Industry, 290 J. AM. Med. Ass'N 252 (2003); Don A. Moore \& George Loewenstein, Self-Interest, Automaticity, and the Psychology of Conflict of Interest, 17 Soc. Just. Res. 189 (2004). 


\section{Consequences of the Lobbyist-Constituent Agency Problem for the Legislative Process}

The fact that lobbyists are imperfect agents may mean that their clients overpay for lobbying services. Because the value of a lobbyist's services is difficult to measure, a client may pay premium rates for what may be suboptimal effort on the lobbyist's part. This may be a socially undesirable deadweight cost, although that normative conclusion is debatable. This Essay, however, is not particularly interested in this sort of "over-billing" problem. Rather, it focuses on whether the lobbyist-constituent agency problem leads to public policy decisions that differ systematically from what one would expect in a "pure" pluralist system. While the impact of the lobbyist-constituent agency problem on public policy is likely to depend on context, this Essay advances four tentative hypotheses about the systematic effects that this agency problem is likely to have on legislative outcomes. These hypotheses are admittedly speculative, based principally on extrapolations from principal-agent theory and plausible, though contestable, assumptions about lobbyist interests and the nature of the legislative process. Rigorous empirical scrutiny to test these and other hypotheses is left to future work, with the recognition that empirical validation of these theories will pose considerable challenges, as it will often be difficult to identify cases where the actions of lobbyists are irrefutably in conflict with the interests of their clients. ${ }^{41}$

\section{A. Hypothesis \#1: The Lobbyist-Constituent Agency \\ Problem Exacerbates Power Asymmetries Between Concentrated and Diffuse Interests}

A standard argument in the literature on interest group pluralism is that small, concentrated, homogenous groups have an advantage over large, diffuse, heterogeneous groups because it is easier for smaller groups to overcome collective action problems and to mobilize members to advance the

${ }^{41}$ Actions in blatant conflict with client interests would usually be easily observable at the time of the lobbying and thus subject to direct principal control. In closer cases, there will often be plausible arguments that the interests of lobbyists and clients are aligned in most material respects. In addition, even when a lobbyist's position clearly did not serve a client's interests in retrospect, it is always possible that the position was taken in error and with the client's express and knowing acquiescence. There are, however, some cases where the totality of circumstances suggests that at least some lobbyists are not pursuing client interests. For example, during the Clinton Administration, the Treasury Department proposed the creation of a new council of financial regulators to resolve inter-agency disputes. The proposal was opposed by nearly every financial services lobbying group on the grounds that the council would disadvantage the interests of each client group. See Dean Anason, Financial Council's Power, Scope, Makeup Criticized, Am. BANKer, June 27, 1997, at 3. While the proposal would have undoubtedly shifted the nexus of regulatory powers, it seems implausible that every group (many of which had diametrically opposed economic interests) would have been injured by the proposed reforms. It is more likely that the lobbyists were reflexively steering their clients away from a new and unfamiliar regulatory structure. 
group's interests. ${ }^{42}$ The agency problem identified in this Essay may exacerbate this power asymmetry. As it becomes more difficult for the client-principals to monitor lobbyist-agents, the more likely it is that the lobbyists will "shirk," making insufficiently vigorous efforts on the principals' behalves or pursuing results that do not quite match the principals' goals.

Single entities or small concentrated groups are likely to be better able to monitor their lobbyist-agents than large, diffuse groups. Trade associations may present a similar monitoring problem for their members, both because heterogeneity of membership implies heterogeneity of interests and because a large membership organization will confront a greater free-rider problem with respect to monitoring. The benefit of this is that concentrated interest groups are likely to get more lobbyist "bang for their buck" than large heterogeneous groups. ${ }^{43}$ This gives concentrated interest groups an additional advantage in the legislative process. This advantage may persist even if large, diffuse groups find a way to overcome the initial collective action problem by agreeing to contribute to a broad-based membership organization. ${ }^{44}$

\section{B. Hypothesis \#2: The Lobbyist-Constituent Agency Problem Leads to an Excessive Focus on Symbolic Issues and Insufficient Clarification of Problematic Issues}

As Part II noted, constituents often rely on their lobbyists for information and advice about which issues they should be concerned about and where they should invest their resources in attempting to influence the legislative process. Lobbyist and client interests may align to a considerable de-

${ }^{42}$ See Olson, The Logic of Collective Action, supra note 3; Olson, The Rise And Decline of Nations, supra note 3.

${ }^{43}$ A possible example here would be the prominent role that the U.S. Chamber of Commerce has taken in opposing the Obama administration's proposal to create a Consumer Financial Protection Agency. See Perspectives on the Consumer Financial Protection Agency: Hearing Before the H. Comm. on Financial Servs., 111th Cong. (2009) (statement of Andrew J. Pincus, Partner, Mayer Brown LLP), available at http://www.house.gov/apps/list/hearing/ financialsves_dem/pincus_-_chamber.pdf. While some aspects of the proposed legislation may have created concerns for certain segments of the Chamber's membership, the group's wholesale and well-funded attack on many aspects of the administration's proposal-including provisions aimed primarily at regulated banks-seems unlikely to have been the kind of governmental action that would have been a major concern to the Chamber's hundreds of thousands of business and organizational members. See also Lisa Lerer, White House Plan: Neuter the Chamber, Politico, Oct. 19, 2009, http://www.politico.com/news/stories/1009/ 28445.html (chronicling disputes between the Obama administration and the Chamber of Commerce on financial regulatory reform and other issues).

${ }^{44}$ As Part II suggests, the agency problem might sometimes lead a lobbyist to exert more effort than the principal desires. For example, high-profile lobbying successes may confer private benefits on the lobbyists themselves, such as personal satisfaction or future employment opportunities. In these cases, one might observe an opposite asymmetry in which large, diffuse groups lobby more aggressively. Even though this increases the odds that these lobbying efforts will be successful, the result is still a welfare loss for the principals, who, if fully informed, would have allocated their resources differently. 
gree when it comes to identifying major issues of concern because lobbyists want to develop a reputation for spotting important issues early and for dealing with them effectively. Nevertheless, these interests may diverge in systematic ways. For example, lobbyists may have an excessive incentive to identify issues where the potential rewards for the lobbyist appear to be high, even when they are not as high for the client. As a result, lobbyists may sometimes have a strong incentive to make mountains out of molehills: a lobbyist can benefit from making small issues seem significant if the lobbyist anticipates a high probability that lobbying on those issues will produce a positive (or apparently positive) outcome. ${ }^{45}$ Because the client cannot ascertain how much of the credit for success is due to the lobbyist's ability and how much is due to external circumstances, the lobbyist has an incentive to seek out, and exaggerate the importance of, issues on which the lobbyist anticipates an easy victory. This suggests an excessive attention to relatively minor issues and symbolic victories, perhaps at the expense of more significant problems. ${ }^{46}$

The inverse problem may also arise. In an environment of incomplete information, a client may not be able to disentangle how much of the failure was due to the lobbyist's lack of ability and how much was due to factors outside the lobbyist's control. ${ }^{47}$ That means an obvious legislative defeat will cause the client rationally to downgrade its assessment of the lobbyist's performance. A lobbyist may therefore have an incentive to avoid calling its clients' attention to issues and problems that affect the client's interests, but where the lobbyist anticipates there is a good chance of losing. Lobbyists, in other words, may sometimes have incentives to make molehills out of mountains: by minimizing the significance of certain issues, the lobbyist may try to avoid blame for defeat, even if the client would have been better off by raising and confronting the issue. This problem likely occurs less frequently

${ }^{45}$ See Kersh, supra note 7, at 248-49 (noting that lobbyists can generate more business by convincing clients to pay attention to issues the clients had previously ignored or were unaware of than by merely completing an assignment and waiting for repeat business).

${ }^{46}$ For example, when federal banking agencies began to focus on the potential problem of mortgage underwriting several years ago, the Mortgage Bankers Association ("MBA") and many other financial services industry lobbying groups opposed the effort, defending the adjustable rate mortgages as "tried and true credit options" that "helped millions achieve the dream of home ownership." See Letter from John Robbins, Chairman, MBA, to Sen. Chris Dodd (D-Conn.), Chairman, Comm. on Banking, Hous., \& Urban Affairs (Jan. 8, 2007), available at http://www.mortgagebankers.org/files/Advocacy/TestimonyandCommentLeters/MBA Letter_NewGuidanceonNonTraditionalMortgageProductRisk_1-8-2007.pdf. These efforts succeeded in the short-term by diluting the severity of banking agency initiatives, but in retrospect the success did not advance the longer-term interests of the MBA's membership, which suffered greatly when the housing market burst shortly thereafter. A more nuanced approach to the emerging problem of mortgage underwriting might have better protected the interests of MBA members but would have been politically risky for groups like the MBA and therefore arguably less attractive ex ante.

${ }^{47}$ An extensive literature has considered the analogous problem in the context of electoral control of politicians, where the voter may be uncertain how much of the observed outcome is due to the politician's efforts and how much is due to factors beyond the politician's control. Austen-Smith \& Banks, supra note 24, at 121. 
than the tendency to exaggerate small problems, perhaps because it is more difficult for a lobbyist to downplay an issue that is obviously important to an interest group's members.

Sometimes, of course, important issues cannot be ignored. Their salience is too obvious, and any attempt by a lobbyist to downplay the significance of the issue would backfire. Nonetheless, lobbyists' interests in securing apparent victories and in avoiding obvious defeats may lead them to deal with these issues in ways that do not force resolution of the issues as fully as their clients, if completely informed, would prefer. The prevalence of vague legislative language may be one manifestation of this phenomenon. Imprecise or incomplete statutory language is sometimes explained by legislators' interests in avoiding difficult choices. It also may be explained by a legislator's desire to claim to a diverse set of competing interest groups that the legislation benefits them. ${ }^{48}$ While this explanation is logical, it raises a puzzle: why do interest groups fall for this strategy? Why do they not demand greater legislative clarity, if it would be to their advantage? ${ }^{49}$

The lobbyist-constituent agency problem suggests a partial answer. Lobbyists on all sides of a contested issue may benefit from imprecise or incomplete statutes, which allow them to claim victory on behalf of their clients, or at least to avoid the appearance of a clear-cut defeat. They may therefore have little incentive to point out ambiguities and potential problems. The strategy of legislative vagueness is puzzling only if one assumes that interest groups recognize both that vagueness exists and that they would benefit from an attempt to force greater clarity. Yet, if the interest groups rely for information and advice on lobbyists who may share the legislators' interest in short-term evasion of difficult problems, there will likely be more opportunities for this evasion to occur.

One consequence of these problems may be a particular form of status quo bias. It is much easier for a lobbyist to successfully block a legislative initiative than to secure its enactment..$^{50}$ Thus, lobbyists interested in achiev-

${ }^{48}$ See Schoenbrod, supra note 21, at 59; Peter H. Aranson et al., A Theory of Legislative Delegation, 68 Cornell L. Rev. 1, 7, 56-62 (1982-83); Morris P. Fiorina, Legislative Choice of Regulatory Forms: Legal Process or Administrative Process?, 39 PuB. ChOICE 33, 46-52 (1982); Mark A. Graber, The Nonmajoritarian Difficulty: Legislative Deference to the Judiciary, 7 Stud. Am. Pol. Dev. 35 (1993); Eli M. Salzberger, A Positive Analysis of the Doctrine of Separation of Powers, or: Why Do We Have an Independent Judiciary?, 13 INT'L Rev. L. \& ECON. 349, 361-66 (1993).

49 See David Epstein \& Sharyn O'Halloran, Delegating Powers (1999); Jerry L. Mashaw, Greed, Chaos, and Governance 145-48 (1997); Eric A. Posner \& Adrian Vermeule, Interring the Nondelegation Doctrine, 69 U. CHI. L. REv. 1721 (2002).

${ }^{50}$ This bias is built into the structure of federal government, where enactment of legislation typically requires favorable referral of legislative proposals by the relevant committees to the parent chambers, reconciliation of any differences between House and Senate versions, the affirmative vote of both chambers, plus a presidential signature (or the two-thirds supermajorities in each chamber necessary to overcome a presidential veto). This makes it relatively easier to block than to enact legislation. See, e.g., William N. Eskridge, Jr. \& John Ferejohn, The Article I, Section 7 Game, 80 Geo. L.J. 523, 528-33 (1992); Roberta Romano, The Political Dynamics of Derivative Securities Regulation, 14 YALE J. ON REg. 279 (1997). 
ing visible successes and avoiding visible defeats have an incentive to emphasize the importance of blocking alleged threats to client interests and to downplay the importance of securing affirmative policy change. Only the most sophisticated clients are likely to be aware of these incentives, and even they are often over-reliant on lobbyists for strategic and tactical advice. By contrast, clients with less expertise in legislative affairs may be wholly unaware of lobbyist incentives. The lobbyist-constituent agency problem may therefore exacerbate the status quo bias already built into the legislative process.

\section{Hypothesis \#3: The Lobbyist-Constituent Agency Problem Creates an Excessive Incentive to Delegate to Administrative Agencies}

The lobbyist-constituent agency problem may produce an excessive tendency not only to enact vague or symbolic legislation, but also to delegate decision-making authority to administrative agencies. The prevalence of delegation to agencies is well known and much debated. ${ }^{51}$ Some amount of delegation may be inevitable, as it is impossible to foresee all the issues that may arise when an executive agency attempts to implement a general law. ${ }^{52}$ Yet, the amount of delegation to agencies, including frequent delegation of what can only be described as lawmaking power, suggests that something more than technical necessity is driving the expansion of administrative governance.

Scholars have suggested myriad explanations for the legislative tendency to delegate. Some scholars accentuate the positive effects of delegation by focusing on technical expertise and healthy insulation from partisan politics. ${ }^{53}$ Others, who are more critical, emphasize legislative slack and avoidance of responsibility. ${ }^{54}$ Without directly engaging these hypotheses, this Essay suggests that the lobbyist-constituent agency problem may induce more frequent and expansive delegations than would be observed if lobbyists were perfect representatives of their clients. If so, the current type and amount of delegation may be excessive from the pluralist point of view.

There are two reasons that the lobbyist-constituent agency problem may produce a stronger tendency to delegate important policy decisions to administrative agencies. First, as discussed above, the lobbyist-constituent agency problem may produce an excessive tendency to pass ambiguous or incom-

\footnotetext{
${ }^{51}$ See, e.g., Aranson et al., supra note 48, at 7-21.

${ }^{52}$ See Richard A. Posner, Statutory Interpretation: In the Classroom and in the Courtroom, 50 U. ChI. L. Rev. 800, 811 (1983).

${ }^{53}$ See James M. Landis, The Administrative Process (1938); Jonathan Bendor \& Adam Meirowitz, Spatial Models of Delegation, 98 Am. Pol. ScI. Rev. 293 (2004); David Epstein \& Sharyn O'Halloran, The Nondelegation Doctrine and the Separation of Powers: A Political Science Approach, 20 CARdozo L. Rev. 947 (1999); David B. Spence \& Frank Cross, A Public Choice Case for the Administrative State, 89 Geo. L.J. 97 (2000-01).

${ }^{54}$ See Schoenbrod, supra note 21, at 59; Aranson et al., supra note 48, at 7, 56-62; Fiorina, supra note 48 , at 46-52.
} 
plete statutes: the lobbyist can portray the result as a victory to the (incompletely informed) client, or at least can take satisfaction in the fact that the result is unlikely to be considered a defeat. Second, delegation to an agency may enhance demand for the lobbyist's services. If a professional lobbying firm or advocacy group has expertise in lobbying both the relevant administrative agency and the legislature — as is often the case ${ }^{55}$ - then delegation to that agency means that the constituent is likely to retain the lobbyist's services after the legislation is passed. Moreover, to the extent that the lobbyist identifies with the interests of the agency, the lobbyist may be biased in favor of expanding the scope of the agency's authority. Although the client might sometimes prefer delegation, there may be cases when the client, if fully informed, would have preferred a legislative resolution, but where the lobbyist preferred to leave it to the administrative process because the cumulative demand for the lobbyist's services will be higher. ${ }^{56}$

Delegation to an agency may also create more demand for legislative lobbying. As many political scientists have observed, delegating the resolution of an issue to an administrative agency does not eliminate the role of the legislature in addressing that issue because of the importance of legislative oversight in influencing administrative decision-making. ${ }^{57}$ Indeed, some political scientists have suggested that Congress deliberately designs agencies to be inefficient-or, in a softer variant on the same idea, that Congress has insufficient incentives to invest substantial effort into making agencies more efficient-because an inefficient regulatory process creates more opportuni-

${ }^{55}$ See HeINZ ET AL., supra note 12, at 95-98 (finding that many of the lobbyists who participate regularly in lobbying Congress also represent their clients before executive branch agencies).

${ }^{56}$ A possible example of this phenomenon can be seen in a provision of the GrammLeach-Bliley Act of 1999, which expanded the powers of banks to engage in securities activities but left unresolved the appropriate degree of Securities and Exchange Commission ("SEC") oversight of bank securities activities. This left the issue of oversight to the joint resolution of the SEC and the banking agencies. The agencies then spent seven full years implementing new regulations in this area, failing to reach a final decision until Congress adopted another piece of legislation mandating adoption of regulation by September 2007. See Definitions of Terms and Exemptions Relating to the "Broker" Exception for Banks, 72 Fed. Reg. 56,514 (Oct. 3, 2007) (codified in scattered sections of 12 C.F.R. pt. 218 and 17 C.F.R. pts. 240, 247).

${ }^{57}$ See Joel D. Aberbach, Keeping a Watchful Eye: The Politics of Congressional Oversight (1990); Kathleen Bawn, Political Control Versus Expertise: Congressional Choices About Administrative Procedures, 89 Am. Pol. ScI. Rev. 62 (1995); David Epstein \& Sharyn O'Halloran, Administrative Procedures, Information, and Agency Discretion, 38 AM. J. Pol. ScI. 697 (1994); Mathew D. McCubbins et al., Structure and Process, Politics and Policy: Administrative Arrangements and the Political Control of Agencies, 75 VA. L. REv. 481 (1989); Mathew D. McCubbins et al., Administrative Procedures as Instruments of Political Control, 3 J.L. Econ. \& Org. 243 (1987); Mathew D. McCubbins \& Thomas Schwartz, Congressional Oversight Overlooked: Police Patrols Versus Fire Alarms, 28 AM. J. Pol. ScI. 165 (1984); Barry R. Weingast \& Mark J. Moran, Bureaucratic Discretion or Congressional Control? Regulatory Policymaking by the Federal Trade Commission, 91 J. Pol. Econ. 765 (1983). 
ties for legislators to intercede on behalf of particular constituents. ${ }^{58}$ In other words, credit for efficient legislation is dispersed throughout the legislature, but an individual legislator can take full credit for a particular intervention with an agency on a constituent's behalf. This intriguing hypothesis has difficulty, however, accounting for why interest groups, particularly sophisticated interest groups, are willing to accept this. After all, if a sophisticated interest group recognized that an agency's decision-making process were inefficient, it could lobby legislators in each chamber to introduce a regulatory reform bill and observe which legislators voted for or against it. Interest groups, however, may not be good at identifying how or why an administrative process is inefficient, nor may they be particularly good at determining which legislative proposal, if any, might redress the problem. These groups necessarily rely on their lobbyists for information and advice.

The lobbyists, like the legislators, may benefit more from a "casework" system, in which aggrieved constituents frequently seek assistance from legislative overseers to deal with their regulatory difficulties. Therefore, in an environment where monitoring and disciplining lobbyists is imperfect, the lobbyists and legislators may share an interest in preserving a "casework"oriented system, and the lobbyist-constituent agency problem may contribute to the maintenance of that system.

\section{Hypothesis \#4: The Lobbyist-Constituent Agency Problem Promotes Excessive Opposition to Reforms of Decision-Making Processes}

One of the most important possible consequences of the lobbyist-constituent agency problem is that it may produce an excessive status quo bias with respect to decision-making structures and processes. Professional lobbyists have typically invested substantial resources in cultivating the expertise, contacts, and relationships that enable them to represent their clients effectively within the existing system. Situations may arise in which the client would benefit from a substantial change to the existing decision-making process. The client's lobbyist, however, might anticipate that such a change would substantially reduce the value of the lobbyist's specific assets. As a result, the lobbyist might obscure or deemphasize the possibility of such a change. The lobbyist might simply fail to raise it as a possibility, might try to convince the client that it is a bad idea, or might press for it with insufficient effort.

Consider, as a hypothetical example, a proposal to transfer authority over a given industry from a specialized commission to a larger agency with more general regulatory authority. This transfer might benefit firms in the industry for any number of reasons, including greater efficiency and coordination, more professionalism and competence on the part of the regulators in

${ }^{58}$ See Morris P. Fiorina, Congress: Keystone of the Washington Establishment 46-49, 71 (1977); Fiorina, supra note 48, at 46-52. 
the general agency, and so forth. However, the lobbyist for the industry's trade association may have developed distinctive expertise in dealing with the specialized agency - she has established relationships with the commissioners, she is familiar with the internal decision-making processes, she knows the regulatory pressure points, and so forth. The value of this expertise would be diminished if the specialized agency were absorbed into a larger, more generalized agency. The client would still need a representative before the general agency, but there is no guarantee that the client would use the same lobbyist that previously represented it before the specialized agency. As a result, the current lobbyist might oppose the change, even if it would benefit the client. ${ }^{59}$ The same logic applies in the inverse situation, where there is a proposal to transfer authority over a given industry from a general agency to a new specialized agency. Furthermore, if lobbyists identify with particular government agencies-perhaps because of past employment-or seek to curry favor with them-perhaps because of anticipated future employment opportunities - these lobbyists may be reluctant to push proposals that are adverse to the agency's interests, including its interest in self-preservation.

By similar logic, the lobbyist-constituent agency problem may engender an excessive reluctance, or, in some cases, an excessive enthusiasm, for changing the principal locus of government decision-making from the federal government to individual states, or vice versa. Consider, for example, a trade association or advocacy group that is represented by lobbyists who specialize in dealing with Congress and the federal regulatory agencies. These lobbyists are likely to have the expertise and personal contacts that are useful in representing clients' interests in these federal venues. The lobbyists' assets are probably much less useful in pressing their clients' interests before a state legislature or agency. For this reason, these lobbyists might be unenthusiastic about legislative proposals to devolve more regulatory authority to state and local governments, even if doing so would have expected benefits for their clients. ${ }^{60}$

59 The ongoing debates over regulatory reform in the financial services industry offer many possible illustrations of this phenomenon, as many trade groups oppose consolidation of financial supervision in the United States. See, e.g., Gov't Accountability Office, Financial Regulation: A Framework for Crafting and Assessing Proposals to Modernize the Outdated U.S. Financial Regulatory System (2009) (including comments from the American Bankers Association), available at http://www.gao.gov/new.items/d09216.pdf.

${ }^{60}$ Again the on-going financial regulatory reform debates offer possible examples. One of the most contentious aspects of the Obama administration's proposals for consumer protection is the restoration of state supervisory authority of federally chartered depository institutions, such as national banks or federally chartered thrifts. Lobbyists for the financial services industry have generally opposed this aspect of the administration's proposals, preferring to maintain uniform national standards. See, e.g., Letter from Steve Bartlett, President and CEO, The Fin. Servs. Roundtable, to Members of the Comm. on Banking, Hous., and Urban Affairs (July 8, 2009), available at http://www.fsround.org/policy/pstatements/pdfs/FSRReg.REformLtrtoSen ateBanking.pdf. 
The same phenomenon may apply in reverse for lobbyists who specialize in representing clients before state governments. These lobbyists may be excessively hostile to the federalization of issues that have previously been handled at the state level. For example, most major corporations are incorporated in Delaware. ${ }^{61}$ As a result, professional lobbyists who act on behalf of the managers and shareholders of these corporations have developed a special expertise in representing their clients in the Delaware legislature, which has proved quite responsive to their input. ${ }^{62}$ These specialized lobbyists may therefore have self-interested reasons for opposing, and advising their clients to oppose, greater federalization of corporate law, even in contexts where their clients might benefit.

Finally, this same basic logic may promote excessive reluctance to drastically alter the government's regulatory strategy. For example, switching from a "command-and-control" system of regulation, where government agencies play a large role in allocating resources, to a more market-based system might dramatically reduce the value of the specialized expertise of those who only know how to work the existing governmental system. This is not necessarily because the aggregate demand for lobbying services would be lower under a market-based system than under a command-and-control system, though it might be in some cases. The more important consequence is that the shift in regulatory strategy alters the type and nature of expertise that would be valuable to clients, and such changes are therefore threatening to incumbent lobbyists.

Legislative observers generally acknowledge that there is a status quo bias in the legislative process, which can be explained without necessarily invoking a lobbyist-client agency problem. That said, the agency problem may not only exacerbate the status quo bias problem, it may also make the problem especially acute in particular contexts. The lobbyist-client agency problem may partly explain why the bias persists even in contexts where a large coalition of interests would seem to benefit from change. Additionally, while this Essay has emphasized ways in which the agency problem may promote excessive opposition to reforms of decision-making processes, the underlying logic of the argument suggests particular situations in which observers might notice an excessive enthusiasm for certain types of changes. Where, for example, lobbyists anticipate that a process reform would enhance the value of their specialized assets, they may push for it with enthusiasm, even if the benefits to their clients are questionable. Similarly, just as lobbyists may have an excessive taste to delegate to agencies, they may also have an excessive taste for complex procedures, as these create greater

${ }^{61}$ See Mark J. Roe, Delaware's Half-Life, STAN. L. REv. (forthcoming 2010) (manuscript at 1 , on file with authors).

${ }^{62}$ See Leo E. Strine, Jr., Delaware's Corporate-Law System: Is Corporate America Buying an Exquisite Jewel or a Diamond in the Rough? A Response to Kahan and Kamar's Price Discrimination in the Market for Corporate Law, 86 CoRnell L. REv. 1257, 1268-70 (2000-01). 
ongoing demand for lobbyists' services. This may produce not only a resistance to simplification, but also an enthusiasm for greater complexity than various constituencies' interests would warrant.

Again, the point is not that an interest group's opposition to a change in government decision-making processes, or enthusiasm for delegation to agencies, necessarily arises from an agency problem between the interest group and its lobbyists. In most cases, lobbyists will likely advance positions that do in fact favor their clients' interests. The argument is that there may be a subset of cases at the margin where the lobbyist-constituent agency problem distorts an interest group's behavior in systematic ways.

\section{CONCLuSion}

This Essay has suggested that incomplete information and imperfect monitoring may create a principal-agent problem between lobbyists and the constituencies they represent and advise. It has further suggested that this agency problem may create or intensify systematic distortions in the policymaking process. The lobbyist-constituent agency problem may increase the relative advantages that small, homogenous, concentrated groups already enjoy, as these groups are better able to monitor their lobbyist-agents and reduce agency slack. This agency problem may also engender an overemphasis on small issues and symbolic legislation, as well as vague or incomplete legislation on more important issues. Perhaps most importantly, the lobbyist-constituent agency problem may promote excessive delegation to administrative agencies and an excessive preference for decision-making structures and processes that benefit incumbent lobbyists. This latter effect will usually, though perhaps not always, inhibit programs of structural reform that reshape government operations.

These hypotheses are general, abstract, and tentative. While they are plausible conjectures about the impact of a lobbyist-constituent agency problem on public policy outcomes, both the extent and implications of this agency problem are likely to vary by context and be easily generalized. The central objective of this Essay is not to demonstrate the accuracy of any of these particular hypotheses, but rather to identify the lobbyist-constituent agency problem as a potentially important influence on public policy outcomes - an influence that might systematically distort the outcomes of a pluralist policymaking process away from what one would otherwise expect. 